\title{
Circadian blood pressure pattern and cardiac autonomic functions: different aspects of same pathophysiology
}

\author{
Sirkadiyen kan basıncı paterni ve kardiyak otonomik işlevler: Aynı patofizyolojinin farklı yönleri
}

Sercan Okutucu, Uğur Nadir Karakulak, Giray Kabakçı

Department of Cardiology, Faculty of Medicine, Hacettepe University, Ankara, Turkey

\section{ABSTRACT}

Arterial blood pressure fluctuates with a pattern that follows a circadian rhythm, with a peak in the early morning hours and a trough during nighttime. Nocturnal dipping of arterial blood pressure is part of this normal circadian pattern, and its absence, which is called non-dipping is associated with more severe end-organ damage and increased risk of cardiovascular events, especially in hypertensive patients. Although pathologic mechanisms are still unclear, it has been suggested that non-dippers show impairment in the autonomic system functions that include abnormal parasympathetic and sympathetic activities. Several studies have examined the role of the autonomic nervous system in the non-dipping phenomenon. In this paper, we aimed to review the studies evaluating the relationship between circadian arterial blood pressure pattern and indices of cardiac autonomic functions. (Anadolu Kardiyol Derg 2011; 2: 168-73)

Key words: Autonomic nervous system, biological clocks, blood pressure, cardiovascular system, circadian rhythm, hypertension

ÖZET

Arteriyel kan basıncı sabahın erken saatlerinde zirveye, gece saatlerinde en düşük değerlere ulaşan sirkadiyen bir ritim paterni izlemektedir. Geceleri arteriyel kan basıncındaki düşüş normal sirkadiyen paternin bir parçasıdır. Bu düşüşün görülmediği "non-dipping" olarak adlandırılan sirkadiyen kan basıncı paterni, özellikle hipertansif hastalarda, daha şiddetli hedef organ hasarı ve artmış kardiyovasküler olaylarla birliktedir. Her ne kadar altta yatan mekanizmalar tam olarak bilinmese de "non-dipping" paterni olan kişilerde anormal parasempatik ve sempatik aktiviteleri içeren otonom sistem bozukluğunun olduğu öne sürülmüştür. "Non-dipping" fenomeninde otonom sinir sisteminin rolü birçok çalışmada incelenmiştir. Bu yazıda, sirkadiyen arteriyel kan basıncı paterni ile kardiyak otonomik işlevlerin göstergeleri arasındaki ilişkiyi değerlendiren çalışmaları derlemeyi amaçladık. (Anadolu Kardiyol Derg 2011; 2: 168-73)

Anahtar kelimeler: Otonomik sinir sistemi, biyolojik saatler, kan basıncı, kardiyovasküler sistem, sirkadiyen ritim, hipertansiyon

\section{Introduction}

Circadian rhythm strongly influences human biology and pathology. Almost all functional unit of the human body shows circadian pattern that is under control of biological clock. Cardiovascular functions including blood pressure (BP) and vascular functions also show diurnal oscillation. Circadian type blood pressure rhythm refers to the daily variation of BP that is generally higher during the day than at night. Most of the people present a decline in arterial BP between $10-20 \%$ during nighttime intervals which is called dipper pattern $(1,2)$. Blunted decline in nighttime BP (non-dipping pattern) brings unfavorable cardiovascular outcomes together (3-7). Although pathologic mechanisms responsible for blunted nocturnal fall in blood pressure are still unclear, it has been suggested that non-dippers show impairment in the autonomic system functions that include abnormal parasympathetic and sympathetic activities. There are several studies revealed that both increased sympathetic

Address for Correspondence/Yazışma Adresi: Dr. Sercan Okutucu, Department of Cardiology, Hacettepe University Faculty of Medicine, Ankara, Turkey Phone: +90 3123051781 Fax: +90 3123114058 E-mail: sercanokutucu@yahoo.com

Accepted Date/Kabul Tarihi: 25.01.2011 Available Online Date/Çevrimiçi Yayın Tarihi: 08.02.2011

(C)Telif Hakkı 2011 AVES Yayıncılık Ltd. Şti. - Makale metnine www.anakarder.com web sayfasından ulaşılabilir.

(C) Copyright 2011 by AVES Yayıncillk Ltd. - Available on-line at www.anakarder.com doi:10.5152/akd.2011.031 
and decreased parasympathetic activity have been associated with an increased risk for overall mortality, the decline in vagal tone and increased sympathetic tone might explain the increase in cardiovascular risk in non-dipper subjects (8).

In this review, we aimed to overview biological clocks, circadian blood pressure pattern and the relationship between circadian arterial blood pressure pattern and indices of cardiac autonomic functions.

\section{Biological clocks and circadian blood pressure pattern}

The human body experiences a reproducible rhythm in behavior, waking in the morning and sleeping in the evening-a circadian rhythm. This is a consequence of the brain "resting" and "waking" as evidenced by changes in electrical activity $(1,9)$. Circadian rhythms are generated within the suprachiasmatic nuclei (SCNs) by the regulated expression of clock genes in discrete neuronal populations $(1,9)$. It has been shown that the central oscillator in the SCN is not the only biological clock in the human body, and that the genes of the human biological clock are also expressed cyclically in many peripheral tissues, such as the liver, heart, arteries, skin, and lymphocytes (10). These peripheral clocks are coordinated by the central clock in the SCNs, which is synchronized with the day/night cycle by the direct influence of the ambient light. This central clock then communicates with the peripheral ones via the nervous and circulatory systems, so that these peripheral clocks can in turn synchronize themselves with the central oscillator (10) (Fig. 1).

After the first classification of dipper / non-dipper nocturnal BP in 1988, reductions in the normal nocturnal decline in BP have become a remarkable issue in cardiology practice (3). Individuals who exhibit a diminished nocturnal decline in blood pressure have been reported to have more cardiovascular end organ damage than dippers $(11,12)$. Non-dipping pattern is associated with end organ damage, such as cardiovascular morbidity and mortality (13-15), type 1 and 2 diabetes mellitus (15), chronic kidney disease (16). Beyond this, studies confirmed that diminished nocturnal decline in blood pressure was a predictor of cardiovascular events $(17,18)$. In the Ohasama study in a Japanese population (13) has been shown that each $5 \%$ decrease in the decline in nocturnal BP was associated with an approximately $20 \%$ greater risk of cardiovascular mortality. Importantly, this association was observed not only in hypertensives, but also in normotensive individuals. Currently non-dipping pattern is considered as a novel predictor of cardiovascular diseases and a risk factor for all-cause mortality (19).

The underlying mechanisms responsible for blunted nocturnal fall in BP are not completely understood. Although fluctuation in $\mathrm{BP}$ is closely related endogenous circadian rhythms (biological clocks), autonomic nervous system activity, increasingly recognized as an important pathway that mediates the circadian rhythm, may be one of the most important determinants of the circadian fluctuation of $\mathrm{BP}(20)$. Therefore, it is not surprising that the autonomic nervous system has very important role mediating the circadian variation in blood pressure. In addition, there are some evidences to suggest that non-dippers show impairment in the autonomic system that includes decreased parasympathetic and increased sympathetic nervous system activity $(21,22)$. A variety of markers has been proposed to reflect autonomic activity such as heart rate variability, heart rate recovery after exercise, baroreflex sensitivity and ventricular repolarization dynamics. These markers are useful, simply, reproducible and non-invasive tools for monitoring autonomic nervous system. Several studies have examined the relationship of this autonomic nervous system in the non-dipping phenomenon.

\section{Exercise heart rate recovery and circadian blood pressure pattern}

Heart rate recovery (HRR) after graded exercise is one of the commonly used techniques, which reflect autonomic activity $(23,24)$. An attenuated HRR, which is defined as the inadequate decline in heart rate immediately after exercise, reflects reduced parasympathetic nervous system (PNS) activity $(23,24)$. Kannankeril et al. (25) demonstrated that sympathetic withdrawal also contributes significantly to early HRR, as evidenced by brisk HRR even after atropine administration at maximal exercise. Based on these findings, they suggested that abnormal HRR might be attributable to defect in sympathetic withdrawal and parasympathetic reactivation or both of them. Because of these changes correlate with increased risk of death, it was hypothesized that an attenuated HRR would similarly predict an increased risk of death (26). Furthermore, Chaitman et al. (27) showed that an abnormal HRR response was a surrogate for underlying autonomic dysfunction and the mechanism of increased mortality associated with this finding might be more related to autonomic dysfunction than to the presence or extent of coronary artery disease.

We recently evaluated the relationship between exercise HRR and circadian blood pressure pattern both in hypertensive and normotensive individuals (28). We found that the blunting of the nocturnal fall in BP was associated with a delayed recovery of heart rate after graded maximal exercise in both normotensive and hypertensive groups. This relationship was more prominent in the hypertensive group. We concluded that when the prognostic significance of HRR is considered, hypertensive and normotensive with a non-dipping pattern should be followed closely for adverse cardiovascular outcomes. Corroborating these results, Polonia et al. (29) have also reported an association between the blunting of the nocturnal fall of BP and delayed HRR after graded maximal exercise, but different from the previous study normotensive individuals were not involved.

First minute exercise heart rate recovery curve is a novel concept in exercise physiology. In hyperbolic type, there is early physiologic vagal re-activation and in sigmoid type, there is delayed vagal re-activation. In our study, predominantly type of 


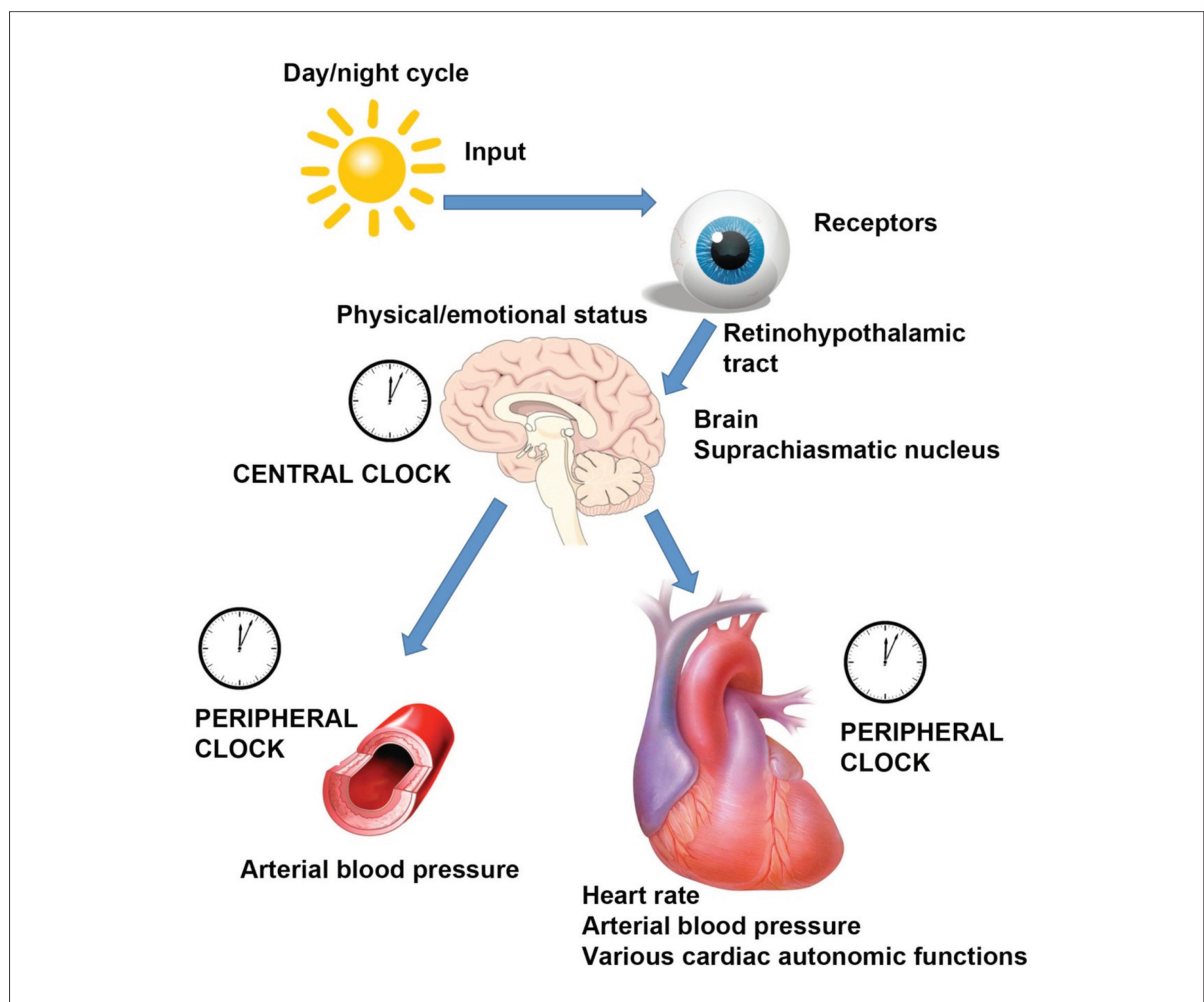

Figure 1. Circadian rhythm and biological clocks

first minute exercise HRR curve was sigmoid in non-dipper population (52.3\% in normotensive/ non-dippers; $68.2 \%$ in hypertensive/ non-dippers) (Fig. 2).

Heart rate variability and circadian blood pressure pattern

Heart rate variability (HRV) analysis is the ability to assess overall cardiac health and the state of the autonomic nervous system responsible for regulating cardiac activity. It is obtained from a 24-hour Holter electrocardiogram (ECG) data and beatto- beat variability of the R-R interval is evaluated. The prognostic significance of HRV in cardiovascular disease is widely reported. Decreased HRV parameters have been associated with increased mortality in patients after $\mathrm{MI}$, with heart failure, ischemic and non-ischemic cardiomyopathy (30-32). Furthermore, some studies have shown that blunted HRV parameters were an important predictor of cardiac involvement in the case of non- cardiac diseases even with free of cardiac symptoms such as ankylosing spondylitis (33). Power spectral analysis of HRV provides useful information on autonomic nervous function as well as the balance between its sympathetic and parasympathetic components (34). Low-frequency band - LF $(0.04$ to $0.15 \mathrm{~Hz})$ which is an index of both parasympathetic and sympathetic nervous activities, shows a nocturnal decrease and high-frequency band-HF ( 0.15 to $0.4 \mathrm{~Hz}$ ), which reflects parasympathetic nervous activity shows a significant increase during nighttime in dipper individuals. Kohara et al. (35) studied 62 essential hypertensive patients and found that diurnal changes in LF and HF were significantly blunted in non-dipper individuals. In the another study, where enrolled 115 stable coronary artery disease patients either hypertensive and normotensive, has been found that some HRV parameters such as pNN50 and RMSSD which are usually correlated with parasympathetic activity were 


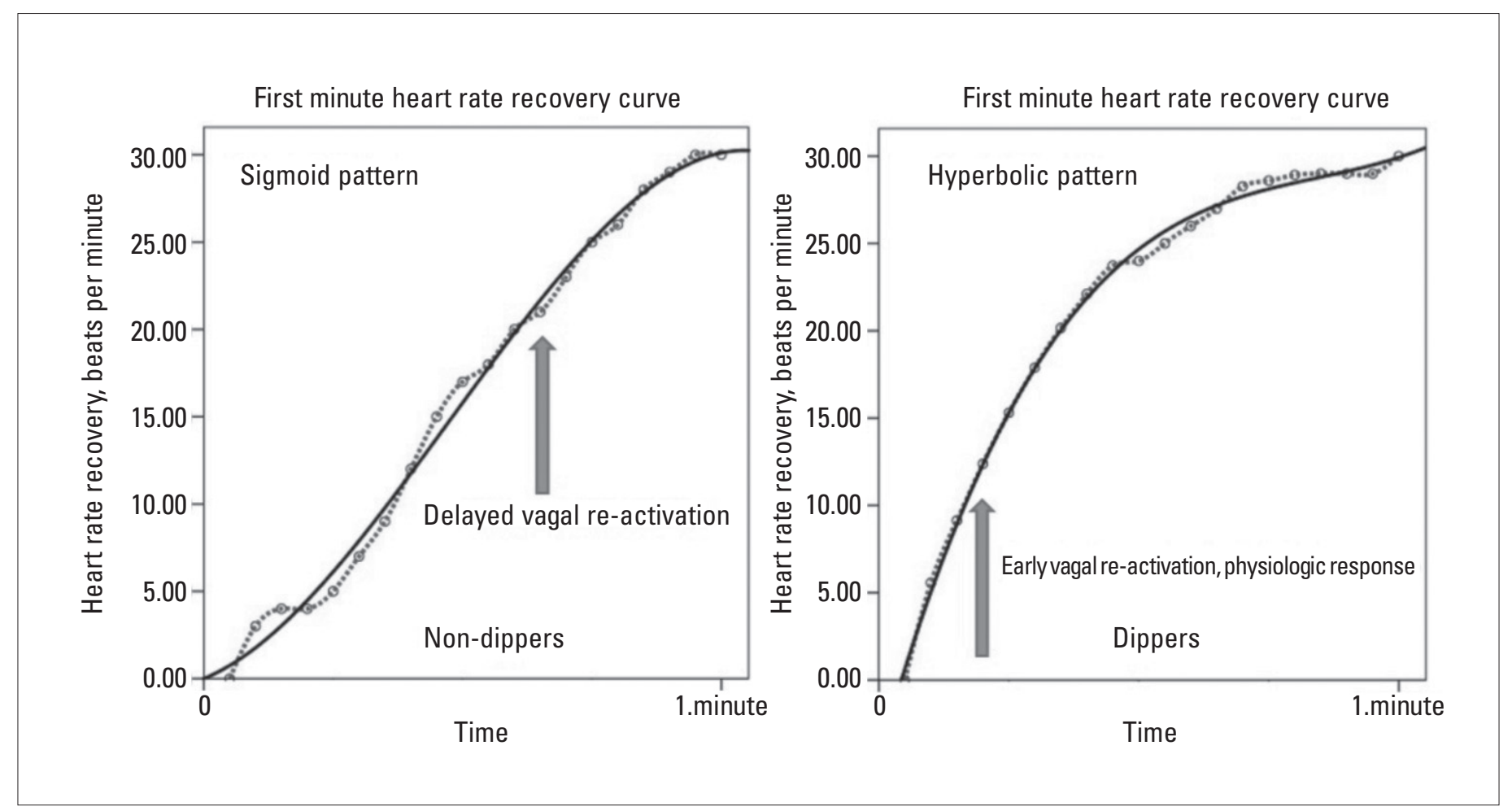

Figure 2. First minute exercise heart rate recovery curves in dippers and non-dippers

lower in the group without a nocturnal fall in BP (36). Based on these findings $\mathrm{HRV}$ analysis shows that physiological function of autonomic nervous system is decreased in non-dipper individuals even in normotensives.

\section{Baroreflex sensitivity and circadian blood pressure pattern}

Baroreflex sensitivity (BRS) is a marker of the capability of reflexes to increase vagal activity and to decrease sympathetic activity in response to a sudden increase in blood pressure. Phenylephrine $(2-4 \mathrm{mg} / \mathrm{kg})$ is given intravenously by at least three bolus injections at intervals of 10 minutes to raise systolic arterial pressure by $15-40 \mathrm{mmHg}$. The evaluation of (BRS) is an established tool for the assessment of autonomic control of the cardiovascular system. Such that changes in the characteristics of baroreflex function, reflect alterations in autonomic control of the cardiovascular system. Thus, measuring the baroreflex has been shown to be a source of valuable information in the clinical management, particularly in prognostic evaluation and assessment of treatment effect, in a variety of cardiac diseases (37). Mortara et al. (38) focused on the prognostic value of BRS testing in 282 patients with heart failure. They found a significantly higher mortality among patients with greatly reduced BRS compared to those with more preserved reflex activity. ATRAMI (Autonomic Tone and Reflexes After Myocardial Infarction) study showed that impaired vagal reflexes expressed by a depressed BRS were significant predictors of total cardiac mortality independently of well-established risk factors such as depressed left ventricular function (39). On the other hand the value and benefit of $B R S$ is controversial. The evidence suggests that BRS is not a reliable risk stratification method and may not have additional benefit over other markers of autonomic tone, such as HRV (33).

Relationship between BRS and circadian arterial blood pressure pattern is not clear. Some studies have revealed that BRS become less sensitive during awakening (40). Others have suggested that there is a circadian rhythm in the sensitivity of the baroreflex, although this was not associated with changes in blood pressure (41). Mancia et al. (42) have found little or no relationship of BRS with circadian blood pressure pattern. In only one study has been researched the association between BRS and non-dipping blood pressure pattern, BRS has not been differed significantly between dippers and non-dippers (43).

\section{Ventricular repolarization dynamics and circadian blood pressure pattern}

Ventricular repolarization is a critical time in the cardiac cycle, playing a considerable role in the pathophysiology of malignant arrhythmias and the OT interval from the standard resting 12-lead ECG is considered as a marker of ventricular repolarization. The lengthening of $\mathrm{QT}$ interval corrected by heart rate (OTc) has been associated with increased risk of either ventricular arrhythmias or sudden cardiac death $(44,45)$. OT dispersion (OTd) which is derived from 12-lead surface ECG is the difference between the maximum and minimum $\mathrm{OT}$ interval. It is accepted as a simple and non-invasive measurement of dispersion of ventricular repolarization. Increased OT dispersion is associated with arrhythmic events in various clinical settings, such as long OT syndrome, heart failure, coronary artery disease, post-myocardial infarction or hypertrophic cardiomyopathy (46). 
QTc interval is also affected by the autonomic nervous system (47). Sympathovagal imbalance leads to increase in OT dispersion. Because underlying pathophysiologic mechanism is similar, there are several studies have been researched the association between non-dipping BP pattern and QT dispersion. Passino et al. (48) have found that QTc interval is prolonged in non-dipper hypertensive patients. Kohno et al. (5) have found that the maximum QTc interval and QTc dispersion were longer in non-dippers than in dippers.

\section{Conclusion}

Nocturnal dipping of arterial BP is part of this normal circadian rhythm, and its absence, which is called non-dipping is associated with more severe end-organ damage and increased risk of cardiovascular events, especially in hypertensives patients. Nondippers show impairment in the autonomic system functions that include abnormal parasympathetic and sympathetic activities. Exercise heart rate recovery indices and heart variability parameters were impaired in non-dipper individuals even in normotensives. Ventricular repolarization dynamics were altered in nondipper hypertensives. When the prognostic significance of these autonomic indices is considered, hypertensives and normotensives with a non-dipping pattern should be followed closely for adverse cardiovascular outcomes.

Given this background future research directions need to include: (i) prospective long-term follow-up of non-dipper subgroups for target organ damage and arrhythmic outcomes both in normotensive and hypertensive groups, (ii) evaluate the involvement of non-cardiovascular autonomic system in different patterns of circadian blood pressure, (iii) assess the relation of circadian blood pressure with autonomic indices, ventricular depolarization and repolarization processes with more sensitive methods like non-linear dynamics, heart rate turbulence, OT dynamicity, T wave alternans or fragmented QRS.

\section{Conflict of interest: None declared.}

\section{References}

1. Biaggioni I. Circadian clocks, autonomic rhythms and blood pressure dipping. Hypertension 2008; 52: 797-8.

2. Fukutomi M, Matsui Y, Shimada K. [Dipper and non-dipper]. Nippon Rinsho 2006; 64 Suppl 6:33-8.

3. Izzedine $\mathrm{H}$, Launay-Vacher $\mathrm{V}$, Deray G. Abnormal blood pressure circadian rhythm: a target organ damage? Int J Cardiol 2006; 107: 343-9.

4. Pierdomenico SD, Lapenna D, Guglielmi MD, Costantini F, Romano F, Schiavone $\mathrm{C}$, et al. Arterial disease in dipper and nondipper hypertensive patients. Am J Hypertens 1997; 10: 511-8.

5. Kohno I, Takusagawa M, Yin D, Okutani M, Mochizuki Y, Sano S, et al. QT dispersion in dipper- and nondipper-type hypertension. Am J Hypertens 1998; 11: 280-5.

6. Shimada K, Kario K. Altered circadian rhythm of blood pressure and cerebrovascular damage. Blood Press Monit 1997; 2: 333-8.

7. Zweiker R, Eber B, Schumacher M, Toplak H, Klein W. "Nondipping" related to cardiovascular events in essential hypertensive patients. Acta Med Austriaca 1994; 21: 86-9.
8. Nakano $Y$, Oshima $T$, Ozono R, Higashi $Y$, Sasaki S, Matsumoto T, et al. Non-dipper phenomenon in essential hypertension is related to blunted nocturnal rise and fall of sympatho-vagal nervous activity and progress in retinopathy. Auton Neurosci 2001; 88: 181-6.

9. Shaw E, Tofler GH. Circadian rhythm and cardiovascular disease. Curr Atheroscler Rep 2009; 11: 289-95.

10. Maemura K, Takeda N, Nagai R. Circadian rhythms in the CNS and peripheral clock disorders: role of the biological clock in cardiovascular diseases. J Pharmacol Sci 2007; 103: 134-8.

11. Henskens LH, Kroon AA, van Oostenbrugge RJ, Haest RJ, Lodder J, de Leeuw PW. Different classifications of nocturnal blood pressure dipping affect the prevalence of dippers and nondippers and the relation with target-organ damage. J Hypertens 2008; 26: 691-8.

12. Shimada K, Kawamoto A, Matsubayashi K, Nishinaga M, Kimura S, Ozawa T. Diurnal blood pressure variations and silent cerebrovascular damage in elderly patients with hypertension. $J$ Hypertens 1992; 10: 875-8.

13. Ohkubo T, Hozawa A, Yamaguchi J, Kikuya M, Ohmori K, Michimata $M$, et al. Prognostic significance of the nocturnal decline in blood pressure in individuals with and without high 24-h blood pressure: the Ohasama study. J Hypertens 2002; 20: 2183-9.

14. White WB. Ambulatory blood pressure as a predictor of target organ disease and outcome in the hypertensive patient Blood Press Monit 1999; 4: 181-4.

15. Spallone V, Maiello MR, Cicconetti E, Pannone A, Barini A, Gambardella S, et al. Factors determining the 24-h blood pressure profile in normotensive patients with type 1 and type 2 diabetes. J Hum Hypertens 2001; 15: 239-46.

16. Portaluppi F, Montanari L, Massari M, Di Chiara V, Capanna M. Loss of nocturnal decline of blood pressure in hypertension due to chronic renal failure. Am J Hypertens 1991;4: 20-6.

17. Verdecchia P, Porcellati C, Schillaci G, Borgioni C, Ciucci A, Battistelli $\mathrm{M}$, et al. Ambulatory blood pressure. An independent predictor of prognosis in essential hypertension. Hypertension 1994; 24: 793-801.

18. Kario K, Pickering TG, Matsuo T, Hoshide S, Schwartz JE, Shimada $K$. Stroke prognosis and abnormal nocturnal blood pressure falls in older hypertensives. Hypertension 2001; 38: 852-7.

19. Brotman DJ, Davidson MB, Boumitri M, Vidt DG. Impaired diurnal blood pressure variation and all-cause mortality. Am J Hypertens 2008; 21: 92-7.

20. Uhl GR, Reppert SM. Suprachiasmatic nucleus vasopressin messenger RNA: circadian variation in normal and Brattleboro rats. Science 1986; 232:3 90-3.

21. Abate G, D'Andrea L, Battestini M, Zito M, Di lorio A. Autonomic nervous activity in elderly dipper and non-dipper patients with essential hypertension. Aging (Milano) 1997; 9: 408-14.

22. Sherwood A, Steffen PR, Blumenthal JA, Kuhn C, Hinderliter AL. Nighttime blood pressure dipping: the role of the sympathetic nervous system. Am J Hypertens 2002; 15: 111-8.

23. Vivekananthan DP, Blackstone EH, Pothier CE, Lauer MS. Heart rate recovery after exercise is a predictor of mortality, independent of the angiographic severity of coronary disease. J Am Coll Cardiol 2003; 42: 831-8.

24. Arena R, Guazzi M, Myers J, Peberdy MA. Prognostic value of heart rate recovery in patients with heart failure. Am Heart J 2006; 151: 851 .

25. Kannankeril PJ, Le FK, Kadish AH, Goldberger JJ. Parasympathetic effects on heart rate recovery after exercise. J Investig Med 2004; 52: 394-401.

26. Goldberger JJ, Cain ME, Hohnloser SH, Kadish AH, Knight BP, Lauer MS, et al. American Heart Association/American College of Cardiology Foundation/Heart Rhythm Society scientific statement 
on noninvasive risk stratification techniques for identifying patients at risk for sudden cardiac death: a scientific statement from the American Heart Association Council on Clinical Cardiology Committee on Electrocardiography and Arrhythmias and Council on Epidemiology and Prevention. Heart Rhythm 2008; 5(10): e1-21.

27. Chaitman BR. Abnormal heart rate responses to exercise predict increased long-term mortality regardless of coronary disease extent: the question is why? J Am Coll Cardiol 2003; 42: 839-41.

28. Okutucu S, Kabakçı G, Deveci OS, Aksoy H, Kaya EB, Aytemir K, et al. Relationship between exercise heart rate recovery and circadian blood pressure pattern. J Clin Hypertens (Greenwich) 2010; 12: 407-13.

29. Polonia J, Amaral C, Bertoquini S, Martins L. Attenuation of heart rate recovery after exercise in hypertensive patients with blunting of the nighttime blood pressure fall. Int J Cardiol 2006; 106: 238-43.

30. Kleiger RE, Miller JP, Bigger JT Jr, Moss AJ. Decreased heart rate variability and its association with increased mortality after acute myocardial infarction. Am J Cardiol 1987; 59: 256-62.

31. Yi G, Goldman JH, Keeling PJ, Reardon M, McKenna WJ, Malik M. Heart rate variability in idiopathic dilated cardiomyopathy: relation to disease severity and prognosis. Heart 1997; 77: 108-14.

32. Okutucu S, Aytemir K, Evranos B, Aksoy H, Sabanov C, Karakulak UN, et al. Cardiac resynchronization therapy improves exercise heart rate recovery in patients with heart failure. Europace 2010. Nov 13. [Epub ahead of print]

33. Kaya EB, Okutucu S, Aksoy H, Karakulak UN, Tülümen E, Özdemir 0 , et al. Evaluation of cardiac autonomic functions in patients with ankylosing spondylitis via heart rate recovery and heart rate variability. Clin Res Cardiol 2010; 99: 803-8.

34. Kamath MV, Fallen EL. Power spectral analysis of heart rate variability: a noninvasive signature of cardiac autonomic function. Crit Rev Biomed Eng 1993; 21: 245-311.

35. Kohara K, Nishida W, Maguchi M, Hiwada K. Autonomic nervous function in non-dipper essential hypertensive subjects. Evaluation by power spectral analysis of heart rate variability. Hypertension 1995; 26: 808-14.

36. Kurpesa M, Trzos E, Drozdz J, Bednarkiewicz Z, Krzeminska-Pakula M. Myocardial ischemia and autonomic activity in dippers and nondippers with coronary artery disease: assessment of normotensive and hypertensive patients. Int J Cardiol 2002; 83: 133-42.
37. Eckberg DL, Convertino VA, Fritsch JM, Doerr DF. Reproducibility of human vagal carotid baroreceptor-cardiac reflex responses. Am J Physiol 1992; 263: R215-20.

38. Mortara A, La Rovere MT, Pinna GD, Parziale P, Maestri R, Capomolla $S$, et al. Depressed arterial baroreflex sensitivity and not reduced heart rate variability identifies patients with chronic heart failure and nonsustained ventricular tachycardia: the effect of high ventricular filling pressure. Am Heart J 1997; 134: 879-88.

39. La Rovere MT, Bigger JT Jr, Marcus FI, Mortara A, Schwartz PJ. Baroreflex sensitivity and heart-rate variability in prediction of total cardiac mortality after myocardial infarction. ATRAMI (Autonomic Tone and Reflexes After Myocardial Infarction) Investigators. Lancet 1998; 351: 478-84.

40. Sleight $P$, Fox $P$, Lopez $R$, Brooks DE. The effect of mental arithmetic on blood pressure variability and baroreflex sensitivity in man. Clin Sci Mol Med Suppl 1978; 4: 381s-2s.

41. Hossmann V, Fitzgerald GA, Dollery CT. Circadian rhythm of baroreflex reactivity and adrenergic vascular response. Cardiovasc Res 1980; 14: 125-9.

42. Mancia G, Parati G, Pomidossi G, Casadei R, Di Rienzo M, Zanchetti A. Arterial baroreflexes and blood pressure and heart rate variabilities in humans. Hypertension 1986; 8: 147-53.

43. Vaile JC, Stallard TJ, al-Ani M, Jordan PJ, Townend JN, Littler WA. Sleep and blood pressure: spontaneous baroreflex sensitivity in dippers and non-dippers. J Hypertens 1996; 14: 1427-32.

44. Schwartz PJ, Wolf S. QT interval prolongation as predictor of sudden death in patients with myocardial infarction. Circulation 1978; 57: 1074-7.

45. Schouten EG, Dekker JM, Meppelink P, Kok FJ, Vandenbroucke JP, Pool J. QT interval prolongation predicts cardiovascular mortality in an apparently healthy population. Circulation 1991; 84: 1516-23.

46. Malik M, Batchvarov VN. Measurement, interpretation and clinical potential of QT dispersion. J Am Coll Cardiol 2000; 36: 1749-66.

47. Moss AJ. The OT interval and torsade de pointes. Drug Saf 1999; 21: 5-10.

48. Passino C, Magagna A, Conforti F, Buralli S, Kozakova M, Palombo $C$, et al. Ventricular repolarization is prolonged in nondipper hypertensive patients: role of left ventricular hypertrophy and autonomic dysfunction. J Hypertens 2003; 21: 445-51. 